\title{
Technetium-99m: From nuclear medicine applications to fine sediment transport studies
}

Jefferson V. Bandeira, Lécio H. Salim

\begin{abstract}
$\overline{\text { Abstract. The present work is a contribution to rescue the history of development of the application of }{ }^{99 \mathrm{~m}} \mathrm{Tc}}$ widely used in nuclear medicine, to its use as tracer for the study of the transport of fine sediment in suspension, in water environment. It addresses the usefulness of its application in obtaining important parameters in environmental studies, illustrating them with some applications already performed and the results obtained. This kind of study, when associated with information on hydrodynamic parameters, for example, river, tidal, wind and wave currents, are powerful tools for the understanding and quantification of fine sediment transport in suspension. Fine sediment is an important vector in the transportation of heavy metals, organic matter and nutrients in water environment, and the quantitative knowledge of its behaviour is mandatory for studies of environmental impacts. Fine sediment labelled with ${ }^{99 \mathrm{~m}} \mathrm{Tc}$, can also be used to study the effect of human interventions, such as dredging of reservoirs, access channels and harbours, and the dumping of dredged materials in water bodies. Besides that, it can be used to optimize dredging works, evaluating the technical and economic feasibility of dumping sites and their environmental impact. It is a valuable support in the calibration and validation of mathematical models for sediment dynamics.
\end{abstract}

Keywords: fine sediment transport $\bullet{ }^{99 \mathrm{~m}} \mathrm{Tc} \cdot$ mathematical modelling $\bullet$ environmental impacts $\bullet$ water environment

\author{
J. V. Bandeira ${ }^{\bowtie}$, L. H. Salim \\ Nuclear Technology Development Center \\ (CDTN/CNEN), \\ Presidente Antônio Carlos Av., 6627, Pampulha, \\ Belo Horizonte - CEP: 31270-901, \\ Minas Gerais - Brazil, \\ Tel.: +55313069 3120, \\ E-mail: jvb@cdtn.br, bandeira178@yahoo.com.br
}

Received: 12 April 2017

Accepted: 14 November 2017

\section{Introduction}

Technetium-99m ( $\left.{ }^{99 m} \mathrm{Tc}\right)$ is, nowadays, the most widely applied radioisotope in nuclear medicine, and its use began in the mid-1960s [1,2]. Features such as emission of gamma radiation of low energy $(140 \mathrm{keV})$ with very good properties for imaging; half-life $=6.02 \mathrm{~h}$; its production in relatively long-lived generators, facilitating supply and use in faraway locations of manufacturing sites, were instrumental for the widespread use of the radionuclide. It is instrumental considering the great value that the use of the nuclear technique represents for the advancement of diagnoses in medicine, which makes nuclear medicine indispensable and very well accepted for the health of humanity for more than 50 years [3].

On the other hand, in the aquatic environment, heavy metals and many organic compounds are usually associated with the fine sediment phase (silt and clay or mud). The fate of these contaminants will be associated with the dynamic behaviour of suspended or bottom sediments in polluted streams. The study of the suspended sediment behaviour is an activity to be accounted for in many environmental studies. Of special interest is the study of individual discharges of contaminants associated to suspended sediments, the short-term dispersion of contaminated material dredged from harbours and reservoirs when dumped 
into water bodies and the behaviour of natural sediment in suspension in bays, estuaries or reservoirs. Tracking for few hours the contaminated suspended sediments introduced into the streams or in the coastal area by individual discharges could allow the quantitative in situ determination of the advection, dispersion, dilution and sedimentation rates [4]. These parameters are important for the calibration and validation of hydrodynamic models that comprise both solid and liquid phases.

Radioactive tracers, in an appropriate chemical form, are used to label fine sediment by chemical sorption, and some of them, such as ${ }^{198} \mathrm{Au}$ and ${ }^{51} \mathrm{Cr}$ have been employed to study the dynamics of fine sediment in suspension. The labelling technique consists of adsorbing the tracer, in an appropriate chemical form, onto the sediment [5]. But these tracers have to be produced in a nuclear reactor each time they are used and require heavy shielding due to the dense flux of high energy gamma radiation they emit. This hampers their use in remote areas.

${ }^{99 \mathrm{~m}} \mathrm{Tc}$ in the form of $\mathrm{TcO}_{4}^{-}$(pertechnetate) has been used for water tracing in short-term hydrological studies [6-8] and seems to be a rather easy radionuclide to be obtained even in countries where nuclear reactors are not available, because of its extended use in nuclear medicine.

A first attempt on using ${ }^{99 m} \mathrm{Tc}$ as a tracer for fine sediment was made in Montevideo Bay, Uruguay, in 1997 [9]. The objective of this application was to study the behaviour of the natural fine sediment in suspension in that bay, which is very polluted, obtaining parameters (advection velocity, dispersion and sedimentation rate) to calibrate a mathematical model. The radioisotope originally selected to label the fine sediment in the Montevideo Bay experiment was ${ }^{198} \mathrm{Au}$, scheduled to be irradiated in IPEN/CNEN nuclear reactor, in São Paulo, Brazil, and transported to Montevideo City by plane. Nevertheless, due to an unforeseen reason, the material did not arrive in time to be used in the programmed experiment. In this way, the two alternatives left were either to cancel the work or try an alternative tracer. The second option was chosen, and the team searched for another radioisotope to label the mud. As there is no nuclear reactor facility in Uruguay, the radioisotopes used in nuclear medicine and received from Argentina by the Center of Nuclear Medicine of the University of the Republic of Uruguay (UdelaR) were the only option. In this way, from the radioisotopes received, ${ }^{99 \mathrm{~m}} \mathrm{Tc}$ was chosen by its half-life and gamma-ray energy. But, being eluted as $\mathrm{TcO}_{4}^{-}$, it was necessary to perform a chemical reduction to transform it into an electropositive colloidal compound, allowing its sorption by the fine sediment, which is electronegative. Two reductants were tested for this purpose: stannous chloride $\left(\mathrm{SnCl}_{2} \cdot 2 \mathrm{H}_{2} \mathrm{O}\right)$ and sodium thiosulfate $\left(\mathrm{Na}_{2} \mathrm{~S}_{2} \mathrm{O}_{3} \cdot 5 \mathrm{H}_{2} \mathrm{O}\right)$. Stannous chloride presented better results in the reduction of ${ }^{99 \mathrm{~m}} \mathrm{Tc}$. The field experiment, performed with this improvised radiotracer, attained its main objectives.

After this first use, and considering the favourable characteristics of ${ }^{99 \mathrm{~m}} \mathrm{Tc}$, as mentioned above, the feasibility of its use for labelling mud, through the chemi- cal reduction of $\mathrm{TcO}_{4}^{-}$eluted from $\mathrm{Mo} / \mathrm{Tc}$ generators was studied in the scope of a detailed research, with regard to the following aspects: 1 - labelling yield as a function of different factors (type and amount of reductant; effect of $\mathrm{pH}$; sediment concentration; contact time; labelling stability); 2 - hydrodynamic behaviour of labelled and not labelled sediment, by means of sedimentation tests. The activities were developed in the laboratories of the Nuclear Technology Development Center (CDTN), Brazilian Nuclear Energy Commission (CNEN), under the IAEA Research Contract BRA-10891 [10-12].

The laboratory tests were successful and this new use of ${ }^{99 \mathrm{~m}} \mathrm{Tc}$ allowed the interesting results already obtained in various applications: Pampulha Hydrographic Basin (Brazil) [13-15]; Orinoco River (Venezuela) $[16,17]$; environmental impact due to the fine sediment originated from the bottom discharge of a small hydroelectric power plant on Paraibuna River (Brazil) [18-20], among others.

The work performed in the laboratory research and in some field applications (e.g., almost all the field work for Pampulha dredging reservoir studies) used second week generators obtained, at no cost, from nuclear medicine laboratories. The reason being that the ${ }^{99 \mathrm{~m}} \mathrm{Tc}$ detector for environmental applications is placed into the water, in $4 \pi$ geometry and for medical applications it is situated externally to the patient which makes a huge difference in terms of counting efficiency. So, the necessary activity concentrations for environmental use $(\mathrm{Bq} / \mathrm{mL}$ of water) are much lower $\left(10^{-7}\right)$ than in nuclear medicine utilization $(\mathrm{Bq} / \mathrm{mL}$ of blood) [13].

The factor $\left(10^{-7}\right)$ was estimated considering the following aspects that defined the activity concentration in:

a) nuclear medicine: a single human patient, when submitted to scintigraphic examinations with the use of ${ }^{99 \mathrm{~m}} \mathrm{Tc}$ can receive, intravenously, up to $40 \mathrm{mCi} /$ day. The amount of blood in an adult human is approximately $75 \mathrm{~mL} / \mathrm{kg}$. Then a person of $80 \mathrm{~kg}$ will have approximately $6 \mathrm{~L}$ of blood;

b) environmental use: the ${ }^{99 \mathrm{~m}} \mathrm{Tc}$ activities used in the field experiments in rivers $[10,13]$ and the volume of water surveyed.

\section{Pampulha reservoir dredging studies - Brazil}

The study was performed to evaluate the viability of an environmental and perennial solution to dredge the fine sediment that accretes $\left(400000 \mathrm{~m}^{3} /\right.$ year $)$ the Pampulha reservoir, in Belo Horizonte City, Brazil, which was facing an accelerated process of reduction of its liquid volume and water surface area (Fig. 1). With this tendency, the reservoir could lose two of the main purposes for which it was built: flood damping and leisure region, with its water surface indubitably linked to the buildings designed in the 1940 decade by the famous Brazilian architect Oscar Niemeyer, forming the architectonic complex that is the landmark of the modern Brazilian architecture being considered the World Heritage of Humanity since 2016. 

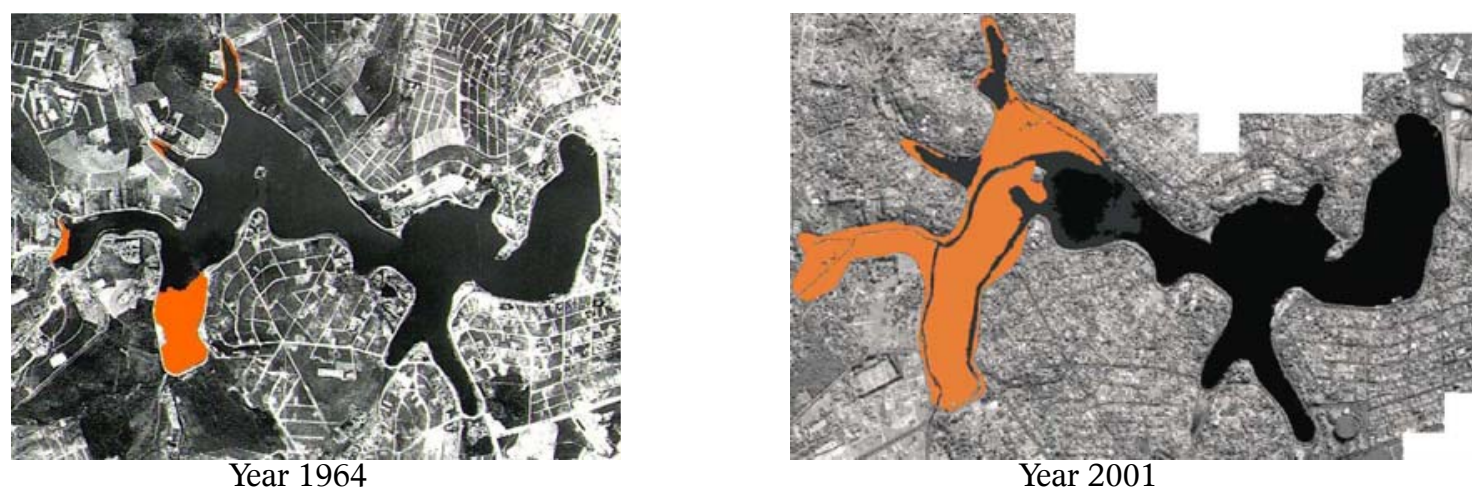

Fig. 1. Pampulha reservoir accretion (in orange), Belo Horizonte, Brazil.

There was no available area inland to dump the dredged material from the reservoir. The watercourses downstream the dam are the natural way for the sediment that accretes the reservoir, if the dam was not constructed. In this way, field experiments, with simultaneous and instantaneous injections of sediment and water labelled, respectively, with ${ }^{99 \mathrm{~m}} \mathrm{Tc}$ and rhodamine WT, were performed, in dry season, in 2000 and 2001, to measure the hydro-transport capability downstream the dam. Static (Eulerian) detections detectors were placed along the river at fixed points to measure the count rate vs. time - were performed at stations D1 to D9 (Fig. 2), covering a stretch of $25 \mathrm{~km}$.

The above referred experiments allowed comparing the different hydrodynamic behaviours of the mud in suspension and the water transporting it [13, 15]. A mathematical model [21] was applied and calibrated to the data obtained: advection velocity and longitudinal dispersion. Table 1 [13] presents the results obtained.

Through convolution, the sediment dumping in suspension using a hydraulic dredging system was simulated, also calculating the physical environmental impacts: increase of sediment concentration and the possibility of deposition. The measurement of physicochemical parameters of the water allowed to evaluate the possibility of desorption of the metals adsorbed in the sediment to be dredged, and dumped downstream.

As for the impacts studied, it was concluded that there was no impediment to the dumping of fine material in the water courses downstream from Pampulha reservoir.

\section{Orinoco River suspended sediment studies using ${ }^{99 \mathrm{~m} T \mathrm{Tc}}$ - Venezuela}

Radiotracer studies were performed in April 2006 in Orinoco River, Venezuela, in the stretch Guarguapo-Barrancas-Ya Ya (Fig. 3), under the IAEA TC project VEN/8/019: "Management of sediments throughout the navigation channel of the Orinoco River", in order to evaluate the bottom and suspended sediment

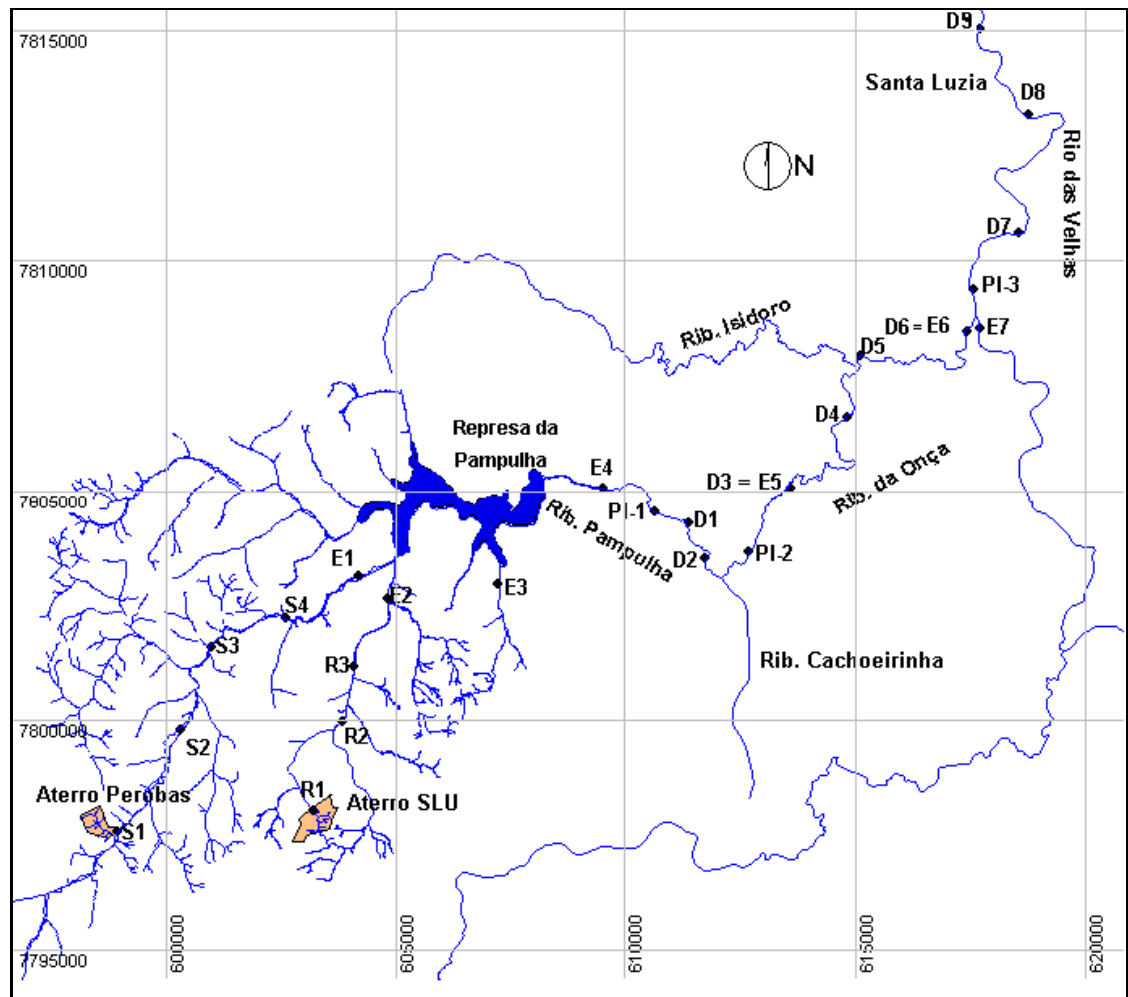

Fig. 2. Studied region in Pampulha Hydrographic Basin and Velhas River [13].
PI-1 to PI-3: Injection points (instantaneous injection of fine sediment and water labelled, respectively, with ${ }^{99 m} \mathrm{Tc}$ and Rhodamine WT). Stations D1 a D9: Eulerian detection of the radioactive \& fluorescent tracer plumes. Obs.: Rib. Pampulha = Pampulha Creek; Rib. da Onça = Onça Creek; Rio das Velhas = Velhas River, Aterro $=$ Landfil. 
Table 1. [13] - Values of advection velocity and longitudinal dispersion (Experiments: see Fig. 2).

\begin{tabular}{|c|c|c|c|c|c|}
\hline $\begin{array}{l}\text { Pampulha \& Onça creeks } \\
\text { September 27, 2000 } \\
\text { (Injection in PI-1) } \\
\text { Water } \\
\text { (Rhodamine WT) } \\
\text { Fine sediment } \\
\left({ }^{99 \mathrm{~m}} \mathrm{Tc}\right)\end{array}$ & $\begin{array}{c}\text { Stretch } \\
\mathrm{D} 1-\mathrm{D} 2 \\
v=0.441 \mathrm{~m} / \mathrm{s} \\
\mathrm{D}=9.2 \mathrm{~m}^{2} / \mathrm{s}\end{array}$ & $\begin{array}{c}\text { Stretch } \\
\text { D1-D3 } \\
v=0.741 \mathrm{~m} / \mathrm{s} \\
\mathrm{D}=15.1 \mathrm{~m}^{2} / \mathrm{s} \\
v=0.714 \mathrm{~m} / \mathrm{s} \\
\mathrm{D}=8.8 \mathrm{~m}^{2} / \mathrm{s}\end{array}$ & $\begin{array}{c}\text { Stretch } \\
\text { D2-D3 } \\
v=0.936 \mathrm{~m} / \mathrm{s} \\
\mathrm{D}=5.5 \mathrm{~m}^{2} / \mathrm{s}\end{array}$ & & \\
\hline $\begin{array}{l}\text { Onça creek } \\
\text { October 3, } 2000 \\
\text { (Injection in PI-2) } \\
\text { Water } \\
\text { (Rhodamine WT) } \\
\text { Fine sediment } \\
\left({ }^{99 m} \mathrm{Tc}\right)\end{array}$ & $\begin{array}{c}\text { Stretch } \\
\text { D3-D4 } \\
v=0.379 \mathrm{~m} / \mathrm{s} \\
\mathrm{D}=11.2 \mathrm{~m}^{2} / \mathrm{s} \\
v=0.386 \mathrm{~m} / \mathrm{s} \\
\mathrm{D}=11.9 \mathrm{~m}^{2} / \mathrm{s}\end{array}$ & & & $\begin{array}{c}\text { Stretch } \\
\text { D4-D6 } \\
v=0.344 \mathrm{~m} / \mathrm{s} \\
\mathrm{D}=10.2 \mathrm{~m}^{2} / \mathrm{s} \\
v=0.326 \mathrm{~m} / \mathrm{s} \\
\mathrm{D}=54.0 \mathrm{~m}^{2} / \mathrm{s}\end{array}$ & \\
\hline $\begin{array}{l}\text { Velhas River } \\
\text { June 26, 2001 } \\
\text { (Injection in PI-3) } \\
\text { Water } \\
\text { (Rhodamine WT) } \\
\text { Fine sediment } \\
\left({ }^{99 \mathrm{~m} T c)}\right.\end{array}$ & $\begin{array}{c}\text { Stretch } \\
\text { D7-D8 } \\
v=0.550 \mathrm{~m} / \mathrm{s} \\
\mathrm{D}=16.2 \mathrm{~m}^{2} / \mathrm{s} \\
v=0.541 \mathrm{~m} / \mathrm{s} \\
\mathrm{D}=13.9 \mathrm{~m}^{2} / \mathrm{s}\end{array}$ & $\begin{array}{c}\text { Stretch } \\
\text { D8-D9 } \\
v=0.480 \mathrm{~m} / \mathrm{s} \\
\mathrm{D}=14.6 \mathrm{~m}^{2} / \mathrm{s} \\
v=0.525 \mathrm{~m} / \mathrm{s} \\
\mathrm{D}=24.8 \mathrm{~m}^{2} / \mathrm{s}\end{array}$ & & & \\
\hline $\begin{array}{l}\text { Onça Creek } \\
\text { July 3, } 2001 \\
\text { (Injection in PI-2) } \\
\text { Water } \\
\text { (Rhodamine WT) } \\
\text { Fine sediment } \\
\left({ }^{99 \mathrm{~m}} \mathrm{Tc}\right)\end{array}$ & $\begin{array}{l}v=0.314 \mathrm{~m} / \mathrm{s} \\
\mathrm{D}=12.8 \mathrm{~m}^{2} / \mathrm{s}\end{array}$ & $\begin{array}{c}\text { Stretch } \\
\text { D3-D5 } \\
v=0.282 \mathrm{~m} / \mathrm{s} \\
\mathrm{D}=9.4 \mathrm{~m}^{2} / \mathrm{s} \\
v=0.290 \mathrm{~m} / \mathrm{s} \\
\mathrm{D}=11.4 \mathrm{~m}^{2} / \mathrm{s}\end{array}$ & $\begin{array}{l}v=0.26 \mathrm{~m} / \mathrm{s} \\
\mathrm{D}=7.3 \mathrm{~m}^{2} / \mathrm{s}\end{array}$ & $\begin{array}{l}v=0.300 \mathrm{~m} / \mathrm{s} \\
\mathrm{D}=21.5 \mathrm{~m}^{2} / \mathrm{s}\end{array}$ & $\begin{array}{c}\text { Stretch } \\
\text { D5-D6 } \\
v=0.327 \mathrm{~m} / \mathrm{s} \\
\mathrm{D}=7.2 \mathrm{~m}^{2} / \mathrm{s} \\
v=0.320 \mathrm{~m} / \mathrm{s} \\
\mathrm{D}=30.6 \mathrm{~m}^{2} / \mathrm{s}\end{array}$ \\
\hline
\end{tabular}

transport [16]. The objective of the former study was related to the choice of dumping site for the dredged material in the ship channels. The main objective of the latter was to study the behaviour of fine sediment in suspension: advection velocity, dispersion coefficient, sedimentation rate $\left(S_{R}\right)$ and dilution, taking into account that the fine sediment is the main carrier of heavy metals and other pollut- ants in the water environment. The Orinoco River basin was experiencing, at that time, a fast industrial development with many industries being installed in the river margins and presenting outfall systems discharging into the watercourse.

In relation to the suspended sediment study, two sub-superficial injections of mud labelled with ${ }^{99 \mathrm{~m}} \mathrm{Tc}$ were performed in the points PS-1 and PS-2 (Fig. 3).

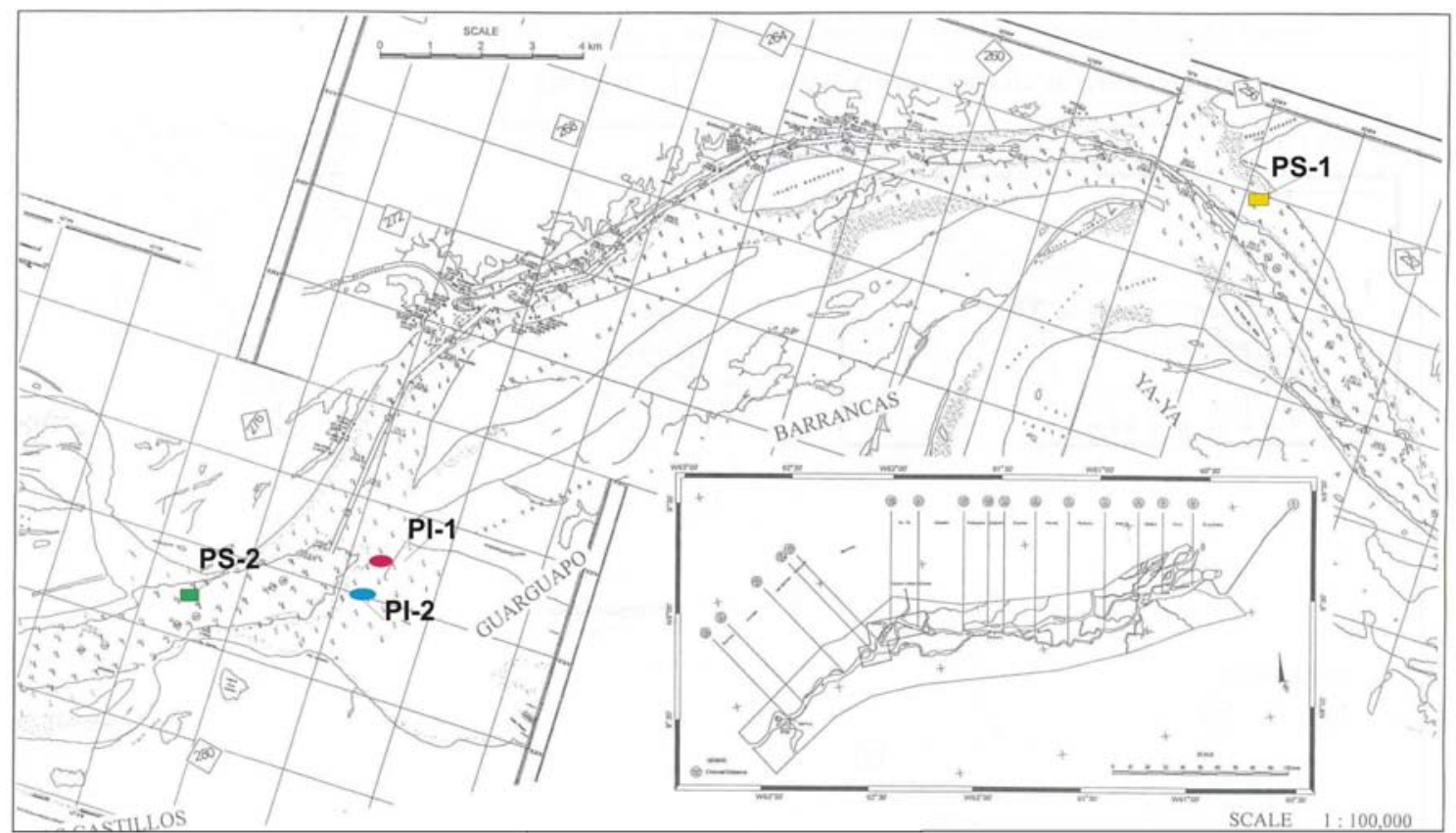

Fig. 3. Map of the sector Guarguapo-Barrancas-Ya Ya, Orinoco River, Venezuela. Note: PS-1 and PS-2 (suspended sediment injection points); PI-1 and PI-2 (bottom sediment injection points). 
Table 2. [17] Results of suspended sediment studies - injection at PS-1 (Fig. 3).

\begin{tabular}{|c|c|c|c|c|c|c|c|c|}
\hline \multirow[t]{2}{*}{ Injection } & \multirow[t]{2}{*}{ Probe } & \multirow{2}{*}{$\begin{array}{c}\text { Sedimentation } \\
\text { rate }\left(\mathrm{S}_{\mathrm{R}}\right) \\
{[\mathrm{g} / \mathrm{ton} / \mathrm{s}]}\end{array}$} & \multicolumn{2}{|c|}{$\begin{array}{c}\text { Dispersion } \\
\text { coefficient }\left[\mathrm{m}^{2} / \mathrm{s}\right]\end{array}$} & \multirow{2}{*}{$\begin{array}{l}\text { Dilution } \\
\text { D }\end{array}$} & \multirow{2}{*}{$\begin{array}{c}\text { Advection } \\
\text { velocity } \\
\mathrm{A}_{\mathrm{V}}[\mathrm{m} / \mathrm{s}]\end{array}$} & \multirow{2}{*}{$\begin{array}{c}T_{\text {half }} \\
{[\mathrm{min}]}\end{array}$} & \multirow{2}{*}{$\begin{array}{l}L_{\text {half }} \\
{[\mathrm{m}]}\end{array}$} \\
\hline & & & $\mathrm{D}_{\mathrm{L}}$ & $\mathrm{D}_{\mathrm{T}}$ & & & & \\
\hline$\overline{1}$ & $1(1.5 \mathrm{~m})$ & 520 & 1.3731 & 0.4949 & \multirow{2}{*}{500} & 0.723 & 22.2 & 963 \\
\hline 1 & $2(0.5 \mathrm{~m})$ & 532 & 1.0811 & 0.4500 & & 0.720 & 21.7 & 937 \\
\hline
\end{tabular}

where:

$\mathrm{D}=$ dilution for the distance $L_{\text {half }}$ referred to the first pick detected just after the injection and considering both detectors; $\mathrm{D}_{\mathrm{L}}, \mathrm{D}_{\mathrm{T}}=$ longitudinal \& transversal dispersion coefficients for the time $T_{\text {half }}$;

$T_{\text {half }}=\ln 2 / S_{R}$ is the necessary time for half of the suspended sediment dumped settles below the diameter of the sphere of influence of the scintillation detector;

$L_{\text {half }}=\mathrm{A}_{\mathrm{V}} * T_{\text {half }}$ is the distance, since the dumping site, for this occurrence.

The initial activities used during the injections were respectively, 2.1 and $1.6 \mathrm{Ci}$ (78 and $59 \mathrm{GBq}$ ). The dynamic (Lagrangean) detection was performed by a boat with two scintillation probes placed at $1.5 \mathrm{~m}$ (probe 1) and $0.5 \mathrm{~m}$ (probe 2) below the water surface. Table 2 [17] presents some results.

The results obtained for the behaviour of the natural sediment in suspension, in the end of the low water season of the Orinoco River (April), could be used for preliminary designs of outfalls for industrial effluents that discharge particulate material with the density of fine sediment or for pollutant material that could be adsorbed by fine sediment.

\section{Environmental impact due to fine sediment originated from bottom discharge of SHP - Brazil}

An R\&D project was developed in 2011-2012, in the region of the Paciência small hydroelectric power plant (SHP) located in the Paraibuna River, Minas Gerais State-Brazil (Fig. 4), with the aim of evaluating, from a multidisciplinary point of view, the environmental impact, downstream the dam, of bottom discharge performed every six months to flush out the sediment and organic matter that accretes this small reservoir [18-20]. The studies were supported by CEMIG - the electric utility company responsible for the operation of the plant. The evaluation was performed through biological, physicochemical and hydro sedimentological studies.

The biological activities were focused on the study of macroinvertebrates of the benthic epifauna gathered in artificial substrates, and sediment sampling for the infauna study. Water samples were collected for physicochemical studies. The hydro sedimentological studies included activities just before and after the bottom discharge of June 2011: sampling of bottom sediment, upstream and downstream the dam followed by granulometric analysis,

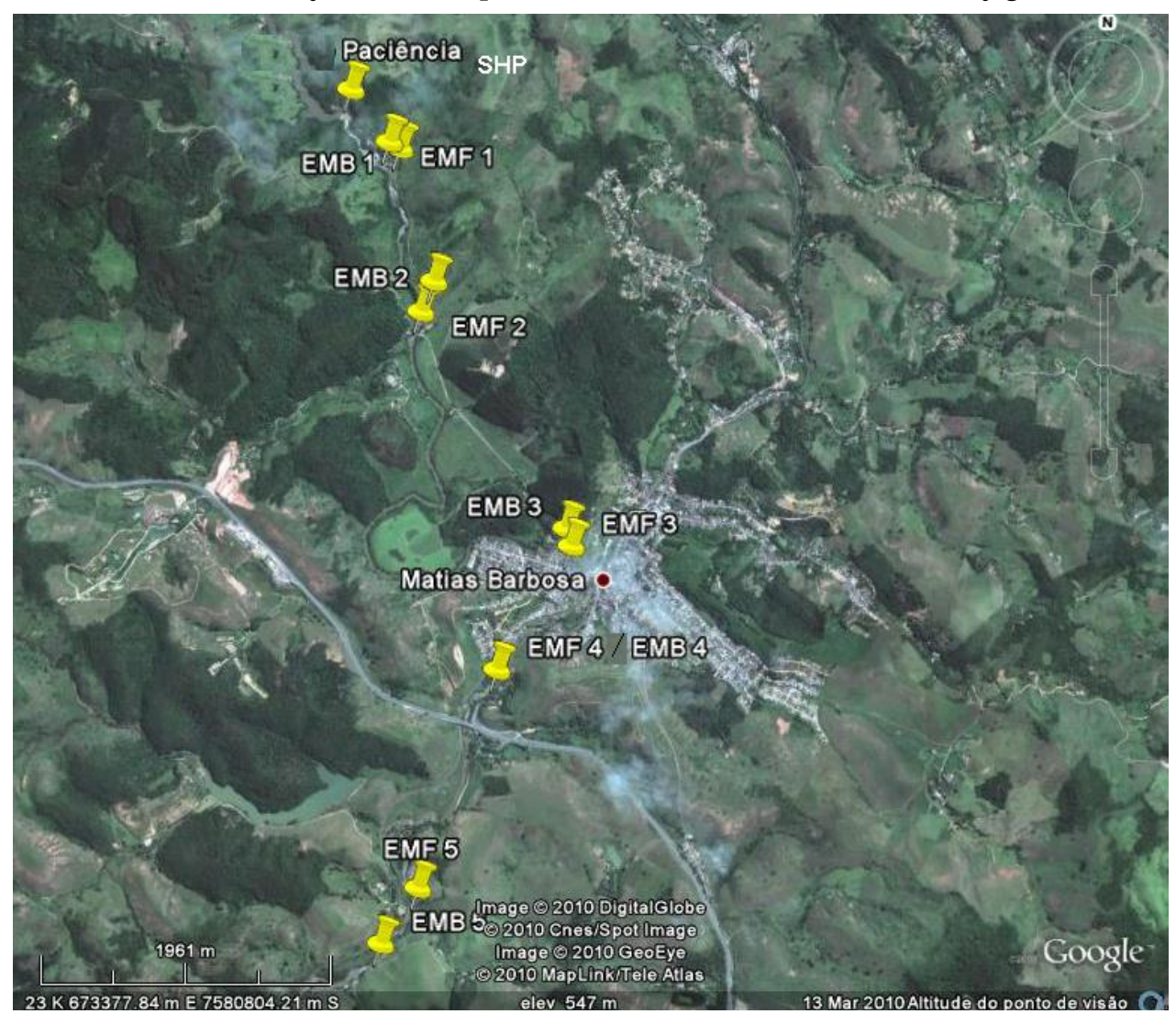

Fig. 4. Area under study, with: EMF (physical) and EMB (biological) monitoring stations. 
Table 3. [20] Values of advection velocity ( $v)$ and dispersion coefficient (D), for all the experiments

\begin{tabular}{|c|c|c|c|}
\hline \multirow{2}{*}{ Stretch } & \multicolumn{3}{|c|}{ Day } \\
\hline & August 21, 2012 & August 22, 2012 & August 23, 2012 \\
\hline \multirow[t]{2}{*}{ EMB2 - EMB4 } & $\begin{aligned} v & =0.39 \mathrm{~m} / \mathrm{s} \\
\mathrm{D} & =9.40 \mathrm{~m}^{2} / \mathrm{s}\end{aligned}$ & $\begin{aligned} v & =0.38 \mathrm{~m} / \mathrm{s} \\
\mathrm{D} & =9.85 \mathrm{~m}^{2} / \mathrm{s}\end{aligned}$ & $\begin{aligned} v & =0.38 \mathrm{~m} / \mathrm{s} \\
\mathrm{D} & =9.00 \mathrm{~m}^{2} / \mathrm{s}\end{aligned}$ \\
\hline & October 24, 2012 & October 25, 2012 & \\
\hline Power house - EMB1 & $\begin{array}{l}v=0.21 \mathrm{~m} / \mathrm{s} \\
\mathrm{D}=5.7 \mathrm{~m}^{2} / \mathrm{s}\end{array}$ & - & \\
\hline EMB1 - EMB4 & $\begin{aligned} v & =0.36 \mathrm{~m} / \mathrm{s} \\
\mathrm{D} & =13.3 \mathrm{~m}^{2} / \mathrm{s}\end{aligned}$ & 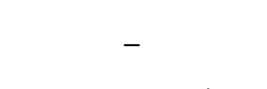 & \\
\hline Power house - EMB2 & - & $\begin{array}{l}v=0.33 \mathrm{~m} / \mathrm{s} \\
\mathrm{D}=5.7 \mathrm{~m}^{2} / \mathrm{s}\end{array}$ & \\
\hline EMB2 - EMB4 & - & $\begin{aligned} v & =0.33 \mathrm{~m} / \mathrm{s} \\
\mathrm{D} & =13.0 \mathrm{~m}^{2} / \mathrm{s}\end{aligned}$ & \\
\hline
\end{tabular}

Obs.: Power house is situated about $430 \mathrm{~m}$ below the SHP dam.

chemical characterization of pollutants in the fine sediment and bathymetric survey in the reservoir, to evaluate its influence in the fluvial system, through the comparison of results obtained.

The transport of fine sediment in suspension downstream the dam was quantitatively studied, by labelling it with ${ }^{99 m} \mathrm{Tc}$. Two field campaigns were performed with a total of five experiments, in August and October of 2012, both during the dry season, being the first under normal operation conditions and the second in situation of bottom discharge of the SHP.

Table 3 [20] presents the results for advection velocity $(v)$ and longitudinal dispersion coefficient (D) for all the experiments performed in the field works, and Fig. 5 shows an example of the results obtained in the field campaigns. It presents the data measured in the two sections and the modelled results for the section downstream, applying a mathematical model [21].

Comparing the areas under the passage curves of the sediment plumes between successive stations, it was possible to calculate the amount of sediment that was trapped between the stations, either by sedimentation/decantation or for becoming temporarily trapped in the dead zones of the water flow. For the hydrodynamic conditions of the experiments conducted in August and October 2012, this retention varied between $8.7 \%$ and $35.2 \%$. It was observed that there was a tendency of higher retention for lower river flow rates.

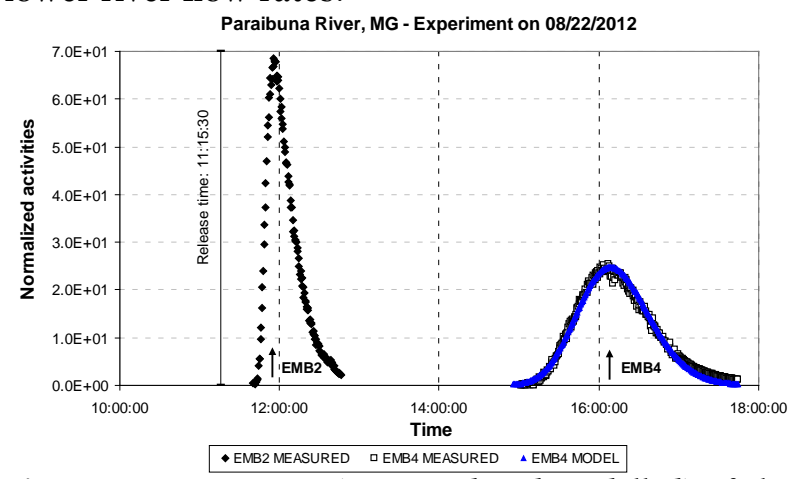

Fig. 5. Passage curves (measured and modelled) of the sediment labelled with ${ }^{99 \mathrm{~m}} \mathrm{Tc}$ in the stations EMB2 and EMB4, in the Paraibuna River, on August 22, 2012.
A mathematical model [21] was calibrated with the results of the tracer experiments and applied to simulate the propagation of a bottom discharge and to estimate the attenuation of the concentration of fine sediments in suspension that had originated from it, in a stretch of $34 \mathrm{~km}$ downstream the Paciência SHP, taking into account the dilution promoted in the Paraibuna River waters by some tributaries (Peixe River and Preto River - Fig. 6).

The simulation was performed for a period of 6 days, comprising 4.5 days of bottom discharge, as shown in Fig. 7. The bottom discharge is performed slowly since the dissolved oxygen (DO) of water, downstream the SHP, should not become smaller

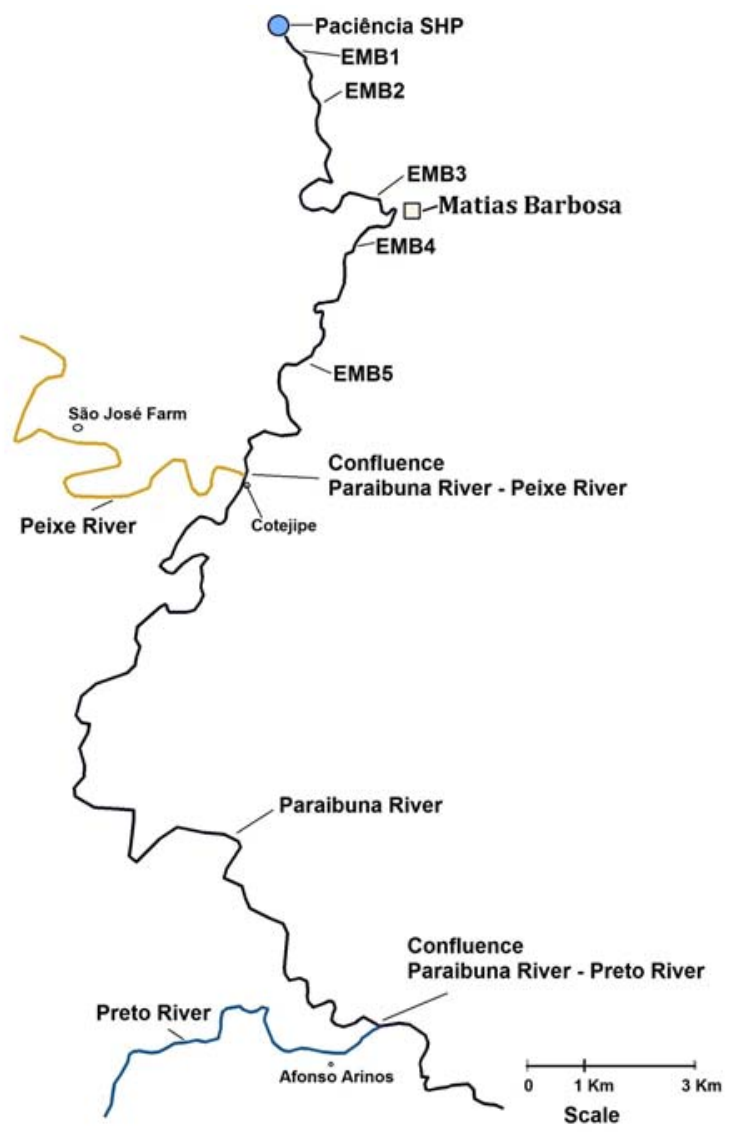

Fig. 6. Paciência SHP and the study region downstream, with the monitoring stations (EMB). 


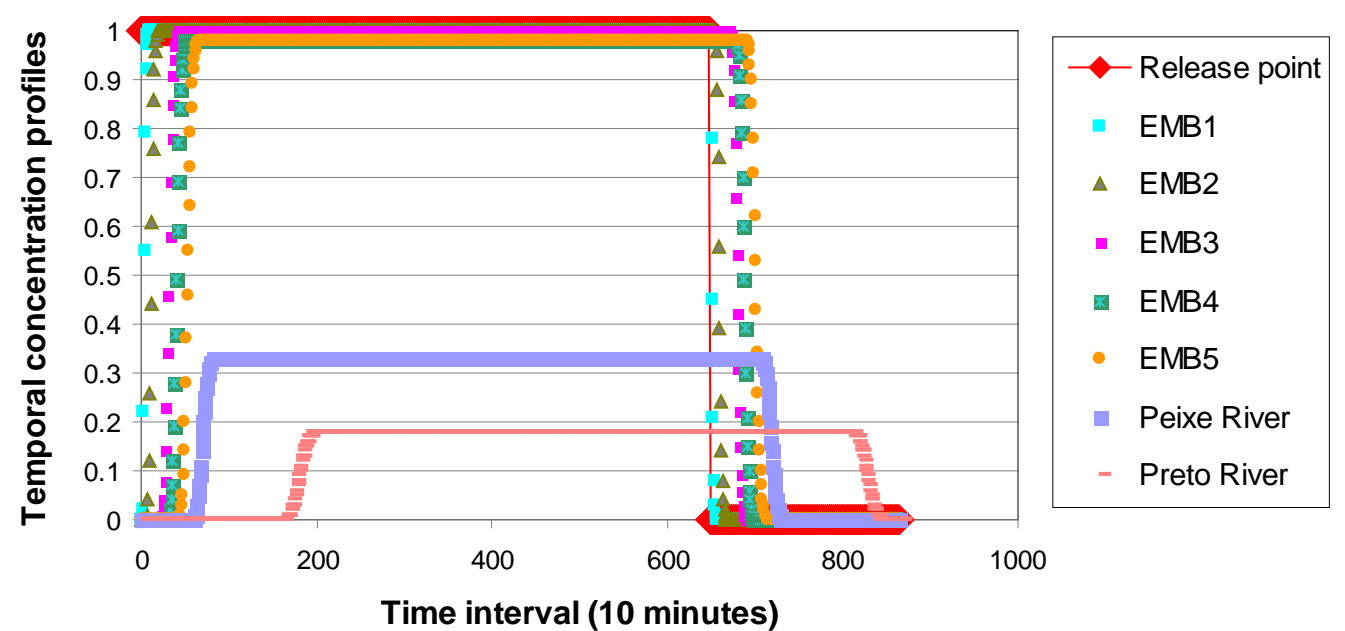

Fig. 7. Temporal representation of the concentration of sediment in suspension due to bottom discharge lasting 4.5 days, considering a unitary concentration in the release point.

than 3, which could compromise the aquatic biota. Minimum measured values of advection velocity, dispersion coefficient, flow rate and dilution were used in this simulation, maximizing the environmental impact of the bottom discharge. This implies, in the permanence of higher concentration of sediment in suspension and higher residence time of the sediment plume in the considered stretch.

\section{Conclusions}

The above-mentioned case studies confirm that labelling of fine sediment with ${ }^{99 m} \mathrm{Tc}$ can be successfully accomplished and that the labelled sediment has the same hydrodynamic behaviour as the natural one.

The application of this radioactive tracer, widely used in nuclear medicine, became available in the field of sedimentology for which the fine sediments are instrumental in the transportation of heavy metals and other pollutants in the water environment [22]. ${ }^{99 \mathrm{~m}} \mathrm{Tc}$ is easy to use due to its simple handling: - Low gamma ray energy (140 keV) implying moderate shielding and ease of manipulation in field conditions by simple elution from the ${ }^{99} \mathrm{Mo} / \mathrm{Tc}$ generator.

- Availability, even in places where there are no nuclear facilities, due to its widespread application in nuclear medicine. Indeed, the possibility of using second week ${ }^{99}$ Mo generator (already used for one week in the nuclear medicine laboratory) facilitates the use of this tracer in environmental studies.

- Convenient half-life of the ${ }^{99} \mathrm{Mo}$ parent nuclide $(66 \mathrm{~h})$, which makes it possible to obtain ${ }^{99 \mathrm{~m}} \mathrm{Tc}$ from the ${ }^{99} \mathrm{Mo}$ generator for one week or more in the field studies. This illustrates the portability of the tracer when compared with ${ }^{198} \mathrm{Au}$, for example, obtained by irradiation in nuclear reactors. The work performed in the laboratory research and in some field applications (e.g., almost all the field work for Pampulha dredging reservoir studies) used second week generators obtained at no cost from the nuclear medicine laboratories. The reason is that the ${ }^{99 \mathrm{~m}} \mathrm{Tc}$ detector for environmental applications is placed in water, in $4 \pi$ geometry and for medical applications it is situated externally to the patient. So, the necessary activity concentrations for environmental use $(\mathrm{Bq} / \mathrm{mL}$ of water) are much lower $\left(10^{-7}\right)$ than in nuclear medicine utilization $(\mathrm{Bq} / \mathrm{mL}$ of blood) [13].

Acknowledgments. The development of the technique for labelling fine sediment with ${ }^{99 \mathrm{~m}} \mathrm{Tc}$ was partially sponsored by the International Atomic Energy Agency (IAEA) through the Research Contract BRA-10891, and was supported by the Brazilian Nuclear Energy Commission (CNEN) through the Nuclear Technology Development Center (CDTN), in whose laboratories the studies were carried out. Dr. Edmundo Garcia Agudo, former IAEA Technical Officer, played a prominent role for the first use of ${ }^{99 \mathrm{~m}} \mathrm{Tc}$ labelling fine sediment, authorizing its realization in the Montevideo Bay studies and in the technical discussions during the subsequent development of the technique in CDTN laboratories. Authors would like to thank the researchers and collaborators from Uruguay, who participated in the IAEA Technical Cooperation Project URU/8/009, outstandingly the Pharmaceutical Chemist Beatriz Souto Ameigenda, for her original idea of trying to replace the scheduled labelling of fine sediment with ${ }^{198} \mathrm{Au}$, by the labelling with ${ }^{99 \mathrm{~m}} \mathrm{Tc}$. Authors would also like to thank their colleagues of CDTN involved in the development of the technique and in the field works performed, especially Dr. Cláudia S. Sabino, for her support in the works performed in the Radiochemistry Laboratory, Eng. Pedro E. Aun and Tech. Vera L. Mendes, for their collaboration in the experiments carried out in the Sedimentology Laboratory and Eng. Virgílio L. Bomtempo, former Head of the Environmental Department of CDTN, for his always available support to the activities here presented. ${ }^{99 \mathrm{~m}} \mathrm{Tc}$ used for the laboratory research and for part of the field work performed in Pampulha studies (Brazil), were donated by ECOGRAF and ECOAR Nuclear Medicine laboratories (Dr. Ivana Sena Nascimento), from Belo Horizonte, and obtained mostly from second week Mo/Tc generators. Special 
thanks to Dr. Patrick Brisset, from the Department of Nuclear Sciences and Applications of IAEA, for his ever-present role in disseminating the use of tracers and nuclear techniques in the study of sediment transport and dispersion of pollutants in water environment.

\section{References}

1. Harper, P. V., Beck, R., Charleston D., \& Lathrop, K. A. (1964). Optimization of a scanning method using technetium-99m. Nucleonics, 22, 50-54.

2. Cherry, S. R., Sorenson, J. A., \& Phelps, M. E. (2012). Physics in nuclear medicine (4th ed.). SaundersElsevier.

3. Lawrence, E., \& Williams, L. E. (2008, June). Nuclear medicine: Fifty years and still counting. J. Med. Phys., 35(7), 3020-3029.

4. Aun, P. E., \& Bandeira, J. V. (1995). The role of nuclear techniques in sedimentological studies and some applications in Latin America. In Use of nuclear techniques in studying soil erosion and siltation, 26-29 April 1993 (pp. 29-97). Vienna: International Atomic Energy Agency. (IAEA-TECDOC-818).

5. Bougault, H. (1970). Etude de la sorption de quelques radioéléments artificiels par les sédiments pélitiques en vue de son application au marquage radioactif de ces matériaux. Doctoral thesis, Faculté des Sciences de l'Université de Paris, France.

6. Borroto, J., Domínguez, J., Pérez, E., Fernández, G., \& García-Agudo, E. (1999). Behavior of ${ }^{99 \mathrm{~m}} \mathrm{Tc}$ in highly polluted surface waters: field and laboratory studies. In International Symposium on Isotope Techniques in Water Resources Development and Management, 10-14 May 1999. Vienna, Austria. CD-ROM ed.

7. Airey, P., Hughes, C., Kluss, T., Duran, E., Miller, B., Chiuenta, S., Nielsen, A. F., \& Hollins, S. (2002). Evolving role of radiotracers in coastal zone studies. J. Appl. Radiat. Isot., 58, 401-406.

8. Borroto, J. (2004). Comportamiento del ${ }^{99 m}$ Tc como radiotrazador en aguas superficiales y residuales. Doctoral thesis in Chemical Sciences. Instituto Superior de Tecnologías y Ciencias Aplicadas. Facultad de Ciencias y Tecnología Nucleares (INSTEC), Departamento de Radioquímica, La Habana, Cuba.

9. Bandeira, J. V., \& Pinto, G. G. (1997). Estudio de la calidad ambiental de la Bahía de Montevideo - Estudios sedimentológicos con la aplicación de técnicas nucleares. End-of-mission report. Vienna: International Atomic Energy Agency. (TC Project URU/8/009).

10. Bandeira, J. V., Pinto, G., Sabino, C. S., \& Agudo, E. G. (1999). The use of ${ }^{99 m} \mathrm{Tc}$ as an adsorbable tracer for studying the dynamics of fine sediments in suspension. In International Symposium on Isotope Techniques in Water Resources Development and Management, 10-14 May 1999. Vienna, Austria. CD-ROM ed.

11. Bandeira, J. V. (2001). The use of the ${ }^{99 m}$ Tc as an adsorbable tracer for studying the dynamics of fine sediments. Final report. Vienna: International Atomic Energy Agency. (Research Contract BRA-10891).

12. Bandeira, J. V., Sabino, C. S., Aun, P. E., Mendes, V. L., \& Agudo, E. G. (2002). Development of a technique for using ${ }^{99 \mathrm{~m}} \mathrm{Tc}$ as an adsorbable tracer for hydrodynamic studies of fine sediments in suspension. J. Appl. Radiat. Isot., 57, 85-92.

13. Bandeira, J. V. (2004). Development of nuclear and correlate techniques for urban hydrology studies - applications in Pampulha Hydrographic Basin and Velhas
River, MG. Unpublished Doctoral thesis in Sanitation, Environment and Water Resources. Federal University of Minas Gerais - UFMG, Belo Horizonte, Brasil.

14. Bandeira, J. V., Salim, L. H., Sabino, C. S., Agudo, E. G., Aun, P. E., \& Mendes, V. L. (2008). ${ }^{99 \mathrm{~m} T c}$ mud labelling and its application in hydrodynamic studies of fine suspended sediment in Brazil. In 5th International Conference on Tracers and Tracing Methods (Tracer 5), 2-6 November 2008. Tiradentes, MG, Brazil. Retrieved March 12, 2017, from http://tracersconferences.com/2006-autranfran1/proceedingtracer5-brasil.pdf.

15. Jung, S. H., Bandeira, J. V., Brisset, P., Wörman, A., Airey, P. L., \& Hughes, C. E. (2015). Radiotracer applications: Case studies from four continents. In Use of radiotracers to study surface water processes (pp. 79-104). Vienna: International Atomic Energy Agency. (IAEA-TECDOC-1760).

16. Bandeira, J. V., Salim, L. H., \& Brisset, P. (2006). Management of sediments throughout the navigation channel of the Orinoco River - bottom and suspended sediment transport evaluation, in Orinoco River, using radioactive tracers. End-of-mission report. Vienna: International Atomic Energy Agency. (TC Project VEN/8/019).

17. Machado, M. L., Bandeira, J. V., Salim, L. H., \& Moreira, R. M. (2008). Orinoco River suspended sediment studies using ${ }^{99 m} \mathrm{Tc}$ - Venezuela. In 5 th International Conference on Tracers and Tracing Methods (Tracer 5), 2-6 November 2008, Tiradentes, MG, Brazil. Retrieved March 12, 2017, from http://tracers-conferences.com/2006-autranfran1/ proceeding-tracer5-brasil.pdf.

18. Bandeira, J. V., Salim, L. H., Junqueira, M. V., \& Barbosa, G. H. S. P. C. (2013). Environmental evaluation of the Paraibuna River downstream of Paciência SHP reservoir, after bottom discharges. Final report. CDTN/CETEC, Belo Horizonte. (R\&D Project GT198 - CEMIG/ANEEL).

19. Bandeira, J. V., Salim, L. H., Ferreira, V. V. M., Junqueira, M. V., Barbosa, G. H. S. P. C., Carvalho, M. D., \& Mota, H. R. (2012). Accretion of reservoirs, bottom discharge and evaluation of environmental impacts: case study of Paciência SHP, Paraibuna River, Minas Gerais State, Brazil. In 10th National Meeting on Sediment Engineering - X ENES, 3-7 December 2012, Foz do Iguaçu, PR, Brazil. São Paulo: ABRH. (in Portuguese).

20. Bandeira, J. V., Salim, L. H., Ferreira, V. V. M., Carvalho, M. D., Mota, M. V., Junqueira, H. R., \& Barbosa, G. H. S. P. C. (2014). Evaluation of sedimentological issues, using tracer techniques, regarding a bottom discharge in the Paciencia Small Hydro Power Plant - Brazil. In 7th International Conference on Tracers and Tracing Methods (Tracer 7), 13-15 October 2014, Marrakech, Morocco. CD-ROM ed.

21. Singh, S. K., \& Beck, M. B. (2003). Dispersion coefficient of streams from tracer experimental data. $J$. Environ. Eng., 129(6), 539-546.

22. Förstner, U., \& Schoer, J. (1984). Some typical examples of the importance of the role of sediments in the propagation and accumulation of pollutants. In Research Co-Ordination Meeting on the Role of Sediments in the Accumulation and Transport of Radionuclides in Waterways, 1982, Mol, Belgium. Introductory lectures: sediments and pollution in waterways. General considerations (pp. 137-158). Vienna: International Atomic Energy Agency. (IAEATECDOC-302). 